\title{
Role of basophil activation test for monitoring the immunological changes during desnsitization to cow's milk: a case report
}

\author{
Valentina Pecora ${ }^{*}$, Eleonora Nucera, Amira Colagiovanni, Alessandro Buonomo, Tiziana De Pasquale, \\ Sonia Musumeci, Angela Rizzi, Arianna Aruanno, Lucilla Pascolini, Anna Giulia Ricci, Vito Sabato, \\ Domenico Schiavino
}

From Food Allergy and Anaphylaxis Meeting 2011 Venice, Italy. 17-19 February 2011

The basophil activation test (BAT) has proven to be a useful tool for the diagnosis of IgE-mediated food allergy and the evaluation of clinical tolerance in food allergic patients. Until now, successful oral desensitization to food allergen has been correlated with changes in cytokine production (IL-4 and INF- $\gamma$ ) and allergenspecific IgE and IgG4 antibodies.

We report a case of a 12-year-old male affected by cow's milk allergy. The diagnosis was based on a positive allergological work-up, included skin prick test with commercial food extracts (Alk-Abellò) and fresh cow's milk (prick-by-prick method), detection in serum of total and specific IgE (ImmunoCAP System, Phadia), basophil activation test and finally a double-blind placebo-controlled food challenge. Skin prick test, specific IgE, BAT and oral food challenge were positive and so we decided to carry on a sublingual-oral desensitization treatment with cow's milk, performed according to standardized protocol. In order to evaluate the immunological changes occurred during the immunotherapy, we performed further laboratory tests, included the detection in serum of total and specific IgE and BAT at the end of protocol.

Desensitization was successfully carried out within 12 months, reaching the maximum dose of $150 \mathrm{ml}$ of cow's milk without side effects. The patient showed a decrease of specific IgE levels without reaching normal values and an increase of specific IgG4 levels; whereas the BAT starting from a positive value of $59 \%$ became negative after 12 months of treatment.

Policlinico A. Gemelli, Allergy Department, Rome, Italy
This case report shows how it is possible to monitor allergen-specific basophil responses using the flow cytometry in order to identify an acquired tolerance induced by desensitization. Although further studies are needed, it was interesting to note that the basophil activation test seems to be more sensitive and characterized by a close correlation with the clinical tolerance.

Published: 12 August 2011

\section{doi:10.1186/2045-7022-1-S1-P95}

Cite this article as: Pecora et al:: Role of basophil activation test for monitoring the immunological changes during desnsitization to cow's milk: a case report. Clinical and Translational Allergy 2011 1(Suppl 1):P95.

Submit your next manuscript to BioMed Central and take full advantage of:

- Convenient online submission

- Thorough peer review

- No space constraints or color figure charges

- Immediate publication on acceptance

- Inclusion in PubMed, CAS, Scopus and Google Scholar

- Research which is freely available for redistribution

Submit your manuscript at www.biomedcentral.com/submit

\section{() Biomed Central}

(c) 2011 Pecora et al; licensee BioMed Central Ltd. This is an open access article distributed under the terms of the Creative Commons Attribution License (http://creativecommons.org/licenses/by/2.0), which permits unrestricted use, distribution, and reproduction in any medium, provided the original work is properly cited. 